Article Type: Research Paper

\title{
The Influence of Transactional Leadership on Organization Innovativeness (OI) Mediated by Organizational Learning Capability (OLC) in Medium Small Enterprise Kendari City
}

\author{
Agniya Thahira, Heru Kurnianto Tjahjono*, and Susanto
}

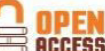

\section{AFFILIATION:}

Universitas Muhammadiyah

Yogyakarta. Yogyakarta. Indonesia

*CORRESPONDENCE:

herukurnianto@umy.ac.id

THIS ARTICLE IS AVALILABLE IN:

http://journal.umy.ac.id/index.php/mb

DOI: $10.18196 / \mathrm{mb} .11190$

\section{CITATION:}

Thahira, A., Tjahjono, H. K., Susanto. (2020). The Influence of Transactional Leadership on Organization Innovativeness (OI) Mediated by Organizational Learning Capability (OLC) in Medium Small Enterprise Kendari City. Jurnal Manajemen Bisnis, 11(1), 90-104.

Received: 27 February 2020

Accepted: 23 March 2020

\begin{abstract}
This study aims to explain the relationship between transactional leadership and organization innovativeness through organizational learning capability as a mediator. This research was conducted at UKM (Small and Medium Enterprises) in the City of Kendari, Southeast Sulawesi. The purposive sampling technique was applied in this study with 125 respondents. The findings in this study are that transactional leadership does not have a significant direct effect on organizational learning capability, but has a positive and significant direct effect on organization innovativeness. The results revealed that organizational learning capability has a very large positive and significant direct effect on organizational innovation, business organizations are expected to maximize their learning processes to create innovations to maintain and develop their existence in the future.
\end{abstract}

Keywords: Transactional Leadership; Organizational Learning Capability (OLC); Organization Innovativeness (OI).

\section{Introduction}

Revolution 4.0 is the biggest challenge for organizations that are currently characterized by significant changes in the business environment. Organizations are faced with the entry of the era known as VUCA (Volatile, Uncertainty, Complexcity, Ambiguity) and organizations need to change themselves to face what is needed by the new environment, more demanding customers, smarter workers, and anticipate the ability to change by accelerating the development of new products, processes and services. Therefore, competitiveness cannot be continued with traditional management approaches in dealing with changes in organizational and leadership settings. The expectations of workers today also experience significant changes. Employees need skills to be more creative and technically competent to be able to work with new technology. Therefore, leaders must attract and motivate (reward, recognize, retain), train, educate and improve the performance of workers. Leaders must fulfill the 
changing of needs and workers expectations, thus leading to the evolution of learning organizations (Singh, 2008). Many studies explain that leaders have an important role in increasing organizational effectiveness (Fawcett, Andraski, Fawcett, \& Magnan, 2009; Tjahjono, 2009; Tjahjono \& Palupi, 2015). Leadership style is one of the most important factors in connection with an organization's capacity to innovate and adapt to change (Eisenbeiss, Van Knippenberg, \& Boerner, 2008).

The small and medium business industry (UKM) is one of the supporting factors in supporting the economy in Indonesia, which is currently being greatly promoted so that its programs are widely promoted by both the government and the private sector. Small and medium businesses (SMEs) are the dominant face of people's livelihood, capital needed is not too large and sufficient income makes many people choose to run this business. Indirectly, UKM is a forum that is able to explore the spirit of entrepreneurs in Kendari City. Entrepreneurship itself is the perspective of making choices to step in the life career. The spirit of entrepreneurship needs to be increased so that the population no longer limits their own fields by merely being stuck as job seekers (Welirang, 2007). The phenomenon suggests that the development of small businesses in seizing business opportunities in Kendari City also plays a role in increasing economic growth and community income. Besides having a strategic position in absorbing labor that has not been absorbed by other economic sectors. In the context of business competition, knowledge is an important source for various organizations. Knowledge can be well-managed by using an organizational learning approach. The rationale for organizational learning aims to develop new knowledge so that the company's human resources are not obsolete, so that the skills and knowledge possessed by employees are dynamic and also improve organizational performance (Morales, Jiménez, \& Gutiérrez, 2012).

Entrepreneurship in the City of Kendari, Southeast Sulawesi (Southeast Sulawesi) currently shows an encouraging growth trend. This can be seen with an increase in small and medium businesses (SMEs) which can be seen in table 1.

The small and medium entrepreneurs are demanded to always learn and create innovations to maintain their existence in the world of entrepreneurship and in spreading entrepreneurial spirit. Learning in this case is referred to an effort to understand and apply strategies to create business continuity, develop businesses, and strategies to help create the seeds of new entrepreneurs in the surroundings. While the intended innovation is the entrepreneur's action to find something new in order to add value to their products, processes and business strategies so that they are superior to competitors.

Table 1 Growth of Small and Medium Enterprises in Kendari City

\begin{tabular}{ccccc}
\hline Year & $\begin{array}{c}\text { Number of } \\
\text { medium business } \\
\text { industries }\end{array}$ & $\begin{array}{c}\text { Percentage } \\
\text { of Increase }\end{array}$ & $\begin{array}{c}\text { Number of small } \\
\text { business industries }\end{array}$ & $\begin{array}{c}\text { Percentage of } \\
\text { Increase }\end{array}$ \\
\hline 2015 & 960 unit & & 2977 unit & \\
2016 & 1133 unit & $18 \%$ & 3662 unit & $23 \%$ \\
2017 & 1450 unit & $28 \%$ & 4578 unit & $25 \%$ \\
2018 & 1653 unit & $14 \%$ & 5219 unit & $14 \%$ \\
\hline
\end{tabular}


The Influence of Transactional Leadership on Organization Innovativeness (OI)...

The ability to learn and create innovation relies heavily on how leaders of an organization can act, the leadership style within an organization will be very supportive in encouraging the learning process and the process of creating innovation can be adopted by employees.

Leadership style is one of the most important individual factors that promote company innovation because leaders can make decisions to introduce new ideas into the organization, set specific goals and encourage innovation among their subordinates (Aragon, García, \& Cordón, 2007). They can also create an environment where employees feel protected, take risks, and therefore more inclined to innovate (Nutt, 2008). Many key determinants of innovation may still not be identified and suggest leadership as one of the issues to be considered in future research (Chang, Chang, Chang, Chi, Chen, \& Deng, 2012; Setiawan \& Tjahjono, 2016).

Transactional leadership is leadership that has a relationship between leaders and subordinates based on the principle of mutual benefit. Transactional leaders give their subordinates material or spiritual tools to be used to achieve the stated goals (Kara, Uysal, Sirgy, \& Lee, 2013). Bass believes that transactional leadership builds the foundation for relationships between leaders and followers in terms of determine expectations, explaining responsibilities, negotiating contracts, and giving acknowledgment and appreciation for achieving expected performance. Applying transactional leadership means that followers agree with, accept, or obey the leader in return for praise, appreciation, and resources or to avoid disciplinary action (Bass, 1985). Gifts and acknowledgment will be given to employees who successfully carry out their roles and tasks (Bass, 1990). The roles and tasks given by the organization become the rationale for organizational learning aimed at developing new knowledge so that the company's human resources are not out of date, so that the skills and knowledge possessed by employees are dynamic and also improve organizational performance (Chang et al., 2008).

Organizational learning is a strategic tool for gaining competitive advantage and stabilizing organizational success by managing the knowledge. The aim of organizational learning is not only to increase employee knowledge and skills but also to develop it to become more flexible and dynamic according to the needs of the organization today (Saadat \& Saadat, 2016). The concept of organizational learning capability (OLC) emphasizes the development of organizational knowledge the importance of creating, managing, and evaluating knowledge-based assets to achieve the integration of individual knowledge into the organizational level (Nonaka \& Takeuchi, 1995).

Innovation is considered as an individual or whole learning process that can find or create a new way to solve problems. The rapidly changed business environment has encouraged managers and researchers looking for new ways to improve an organization's ability to predict the need for change and adaptability for organizational sustainability. Organizational learning aims to enable organizations to adapt to a dynamic environment and improve organizational performance. Thus, organizational learning implies that leaders try to survive in today's complex operating environments (Goh \& Richard, 1997). 
Ultimately, innovation depends on the ability of organizations to learn through developed, distributed, and used of new knowledge (Chiva \& Alegre, 2008).

\section{Literature Review and Hypotheses Development}

\section{A. Transactional Leadership}

Transactional leadership is an exchange representative where superiors and subordinates mutually influence each other so that each gets something of value (Kuhnert \& Lewis, 1987). In explaining this definition, one can define transactional leadership as a leadership approach based on a contractual agreement between a leader and his followers, where each party expects the other party to fulfill the agreed transaction requirements to ensure the continuity of the relationship between them (Penn, 2015). According to Bolden et al., 20 these leadership approaches have become "traditional leadership models with their roots from the perspective of the organization or business in the" bottom line ". Thus, to ensure the achievement of performance (financial) leaders use the formation of parameters, guidelines, rules and certain performance standards plus the establishment of a reward and punishment system to enforce positive work behavior and prevent negative work behavior (Russell, 2011). This situation illustrates that transactional leaders are more task-oriented or objective.

According to Bass (1985) transactional leadership builds the foundation for relationships between leaders and followers in terms of determining expectations, explaining responsibilities, negotiating contracts, and giving recognition and appreciation for achieving expected performance. Showing transactional leadership means that followers agree to accept or obey the leader in return for praise, appreciation, and resources or to avoid disciplinary action. Given prizes and recognition depend on followers who successfully carry out their roles and tasks (Bass \& Avolio, 1990). Specifically, transactional leaders are leaders who operate within the existing system or culture (as opposed to trying to change it) by:

1. Trying to satisfy the needs of current followers by focusing on exchange and contingent reward behavior; and

2. Pay attention to deviations, mistakes, and deviations and take action to make corrections.

Transactional leadership in two dimensions: (1) contingent reward: exchange of contracts for business rewards, promise of rewards for good performance, and recognition of achievements; (2) management with exceptions (active), monitor and look for deviations from rules and standards, and take corrective actions in contingency and active management with exceptions (Bass, 1985). 


\section{B. Organizational Learning Capability (OLC)}

Learning is the main source of competitive advantage. Learning is change, in other words in every organization that requires change to a positive evolution, then learning is a matter of habit (Bowen, Rose, \& Ware, 2006).

Senge (1990) has defined organizational learning as an ongoing process in which employees' individual knowledge is transformed into organizational knowledge. The function of organizational learning is to increase the level of science in the organization and gain a permanent competitive advantage, ie the power of learning faster than competitors is a competitive advantage for organizations. Some other functions in learning include: (1). Improving performance: learning is the most important way to improve performance in the long term and for the short term the organization utilizes the ability, commitment, and ability to learn at all levels of the organization and the best organization claim to be superior, (2). Empowerment of human resources, (3). Creativity and innovation, (4). Organizational learning uses public trust, understanding and science and increases the speed of transforming processes into learning organizations (Akhavan \& Jafari, 2016).

Organizational learning capability $(\mathrm{OLC})$ is defined as the ability of organizations to apply management practices, structures, and procedures that are appropriate to facilitate and encourage learning. Goh \& Richards (1997) use the following dimension constructs:

1. Experimentation refers to the level of freedom that employees use to pursue new ways of doing work and freedom to take risks and which new ideas and suggestions can be used and realized.

2. The clarity of the mission and vision of the organization as a whole, and each unit in it needs to have a clearly articulated mission or goal. Employees need to understand this mission and how their work contributes to achieving it.

3. Leadership commitment and empowerment is described as the role of leader in the organization associated with the process in helping employees learn and bring about behavior that is consistent with experimentation and change.

4. Knowledge transfer and integration consists of two closely related processes, which occur simultaneously and are not sequential, namely: internal transfer and knowledge integration. The effectiveness of these two processes is knowledge absorption capacity which illustrates the lack of internal barriers that prevent the transfer of best practices in the company

5. Team work and group problem solving refers to the level of team work in the organization to solve problems and create new and innovative ideas.

C. Organization Innovativeness (OI)

Organization innovativeness Wang and Ahmed (2014) are defined as "the innovative ability of an entire organization to introduce new products to the market, or open new markets by combining strategic orientation with innovative behavior and processes". 
The Influence of Transactional Leadership on Organization Innovativeness (OI)...

Wang and Ahmed (2014) suggest a five-dimensional classification model for evaluating organizational innovation. These five dimensions consist of factor components of the construct of organizational innovativeness. These dimensions are behavior, products, processes, markets and innovation strategies.

Relationship of Transactional Leadership On Organizational Learning Capability (OLC)

Vargas (2015) describes the importance of building transactional leadership in improving organizational learning capability (OLC). Research by Majd (2017) conducted with the object of profit and non-profit business shows that transactional leadership has influence on the organizational learning capability. From several studies that have been conducted, the authors conclude that transactional leadership has influence on organizational learning capability (OLC) in small and medium businesses (SMEs).

$\boldsymbol{H}_{1}$ : Transactional leadership has a positive and significant influence on organizational learning capability (OLC) in small and medium businesses (SMEs) in Kendari City.

Relationship of Transactional Leadership On Organization Innovativeness (OI)

Research conducted by Aga (2016) on project management of an organization explains that transactional leadership has positive influence on organization innovativeness. From these studies the authors draw the conclusion that transactional leadership has strong influence on organization innovativeness (OI) in small and medium businesses (SMEs).

$\mathrm{H}_{2}$ : Transactional leadership has a positive and significant influence on organization innovativeness (OI) in small and medium businesses (SMEs) in Kendari City.

Relationship Organizational Learning Capability (OLC) On Organization Innovativeness (OI)

Research conducted by Onağ, Tepeci, and Başalp (2014) in several profit organizations states that there is a positive and significant influence between Organizational Learning Capability on Organization Innovativeness. This is reinforced by research conducted by Saadat (2015) which shows that organizational success is based on their organizational learning capability in dealing with a changing and evolving business environment. From a number of studies that have been conducted, the authors can draw the conclusion that organizational learning capability (OLC) has influence on organization innovativeness (OI) in small and medium businesses (SMEs).

$\mathrm{H}_{3}$ : Organizational learning capability (OLC) has a possitive and significant influence on organization innovativeness (OI) in small and medium businesses (SMEs) in Kendari City. 
Relationship Organizational Learning Capability (OLC) as mediator between Transactional Leadership and Organization Innovativeness (OI)

Research conducted by Ebrahimi, Moosavi, Marzieh, and Chirani, (2016), conducted in manufacturing companies in Guilan Province revealed that organizational performance can mediate between transactional leadership in creating a climate of innovation in organizations.

$\boldsymbol{H}_{4}$ : Organizational learning capability $(\mathrm{OLC})$ can mediate the relationship between transactional leadership and organization innovativeness (OI) in small and medium businesses (SMEs) in Kendari City.

\section{Research Method}

Type of research in this study is quantitative research (Tjahjono, 2015), which can be interpreted as research stated in the form of numerical or numerical scales, used to examine populations or specific samples, collecting data using instruments, the data analysis is statistical, and aims to test hypotheses that have been formulated, then it will be tested using AMOS 22. The sampling technique used in this study was purposive sampling. In this study, the sample size is adjusted to the analysis model used, namely Structural Equation Modeling (SEM). In this regard, the sample size for SEM using the maximum likehood estimation (MLE) estimate is 100-200 samples. The primary data collection method in this study was carried out using a survey method, which aims to collect information from respondents using a questionnaire that contains a list of questions submitted directly to respondents, namely the small and medium businesses in the Kendari City area. Measurements in this study consist of numbers on empirical events according to certain rules. The most commonly used form is the Likert scale.

\section{Result and Discussion}

\section{Description of Respondent Characteristics}

Respondents in this study were SME entrepreneurs in Kendari City. The profile data used for respondents in this study were categorized by age, gender, and business periode. This study received 125 respondents so that the number of samples met the SEM rules. The following is the respondent profile data 
The Influence of Transactional Leadership on Organization Innovativeness (OI)...

Tabel 2 Respondent Profile Data

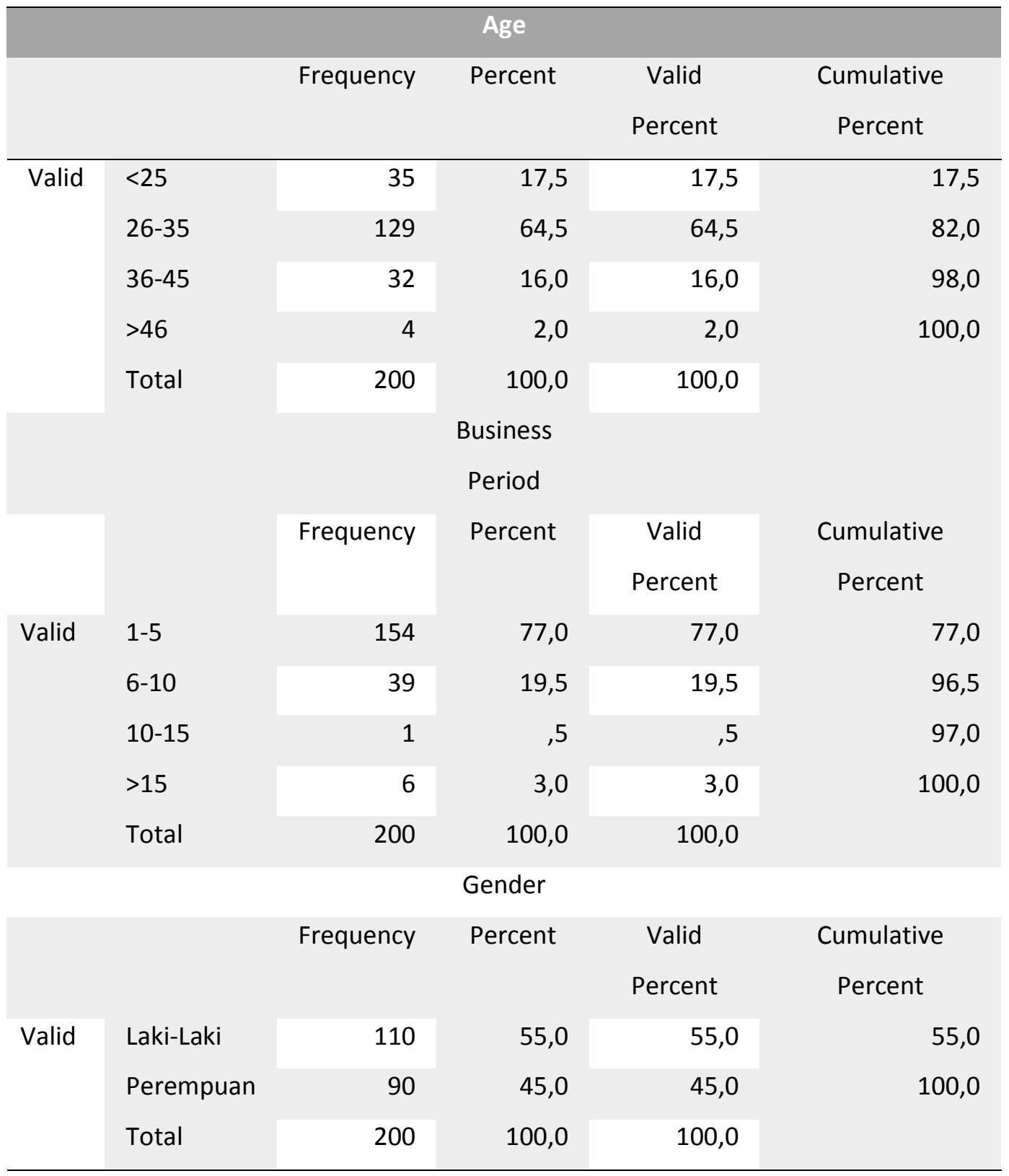

Source: Primary data processed, 2019

2. Instrument Validity and Reliability Analysis

Confirmatory/validity analysis is used to test building concepts using several measurable indicators. In the first confirmatory analysis, the loading factor value of each indicator is seen. The loading factor can be used to measure the construct validity and then a questionnaire can be said to be valid if the questions can express something measured by the questionnaire. The minimum number of loading factors is $\geq 0.5$ or ideally $\geq 0.7$. If there is an indicator value below 0.5 , it would be taken out for further analysis. 
The Influence of Transactional Leadership on Organization Innovativeness (OI)...

Tabel 3 Validity Instrument Test

\begin{tabular}{|c|c|c|c|}
\hline Variable & Item & Estimate & Information \\
\hline \multicolumn{4}{|l|}{ Transactional Leadership } \\
\hline & $\mathrm{x} 7$ & ,658 & Valid \\
\hline & $x 6$ & ,550 & Valid \\
\hline & $\times 5$ & ,696 & Valid \\
\hline & $\mathrm{X} 4$ & ,760 & Valid \\
\hline & X3 &, 529 & Valid \\
\hline & $\mathrm{X} 2$ & ,615 & Valid \\
\hline & $\mathrm{X} 1$ & ,470 & No Valid \\
\hline \multicolumn{4}{|c|}{ Organizational Learning Capability } \\
\hline & Y1.1 & ,317 & No Valid \\
\hline & Y1.2 & ,351 & No Valid \\
\hline & Y1.3 & ,746 & Valid \\
\hline & Y1.4 & ,705 & Valid \\
\hline & Y1.5 & ,615 & Valid \\
\hline & Y1.6 & 671 & Valid \\
\hline & Y1.7 & ,721 & Valid \\
\hline & Y1.8 & ,776 & Valid \\
\hline & Y1.9 & ,748 & Valid \\
\hline & Y1.10 & ,625 & Valid \\
\hline & Y1.11 & ,652 & Valid \\
\hline & Y1.12 & ,690 & Valid \\
\hline & Y1.13 & ,564 & Valid \\
\hline & Y1.14 & ,309 & No Valid \\
\hline & Y1.15 & ,467 & No Valid \\
\hline & Y1.16 & ,374 & No Valid \\
\hline & Y1.17 & ,521 & Valid \\
\hline \multicolumn{4}{|l|}{ Organization Innovativeness } \\
\hline & Y2.1 & ,755 & Valid \\
\hline & Y2.2 & ,420 & No Valid \\
\hline & Y2.3 & ,753 & Valid \\
\hline & Y2.4 & ,743 & Valid \\
\hline & Y2.5 & ,568 & Valid \\
\hline
\end{tabular}

Source: Primary data processed 2019

The reliability coefficient ranges from $0-1$, the higher coefficient means that measuring instrument is more reliable. Reliability construct is good if the construct reliability has value $\geq 0,7$ and the variance extracted value is $\geq 0,5$.

Tabel 4 Uji Reliabilitas Instrumen

\begin{tabular}{lrrl}
\hline \multicolumn{1}{c}{ Variabel } & Construt Realibility & Variance Extracted & Information \\
\hline TSL & 0,8 & 0,4 & Reliabel \\
OLC & 0,9 & 0,5 & Reliabel \\
OI & 0,8 & 0,5 & Reliabel \\
\hline
\end{tabular}

Sumber: Primary data processed 2019 
Variance extracted test is conservative, reliability can be accepted even if the extracted variance is less than 0.50 . So, it can be concluded that the questionnaire used for this study can declared reliable.

3. Testing the Goodness of Fit Assumptions of the SEM Model

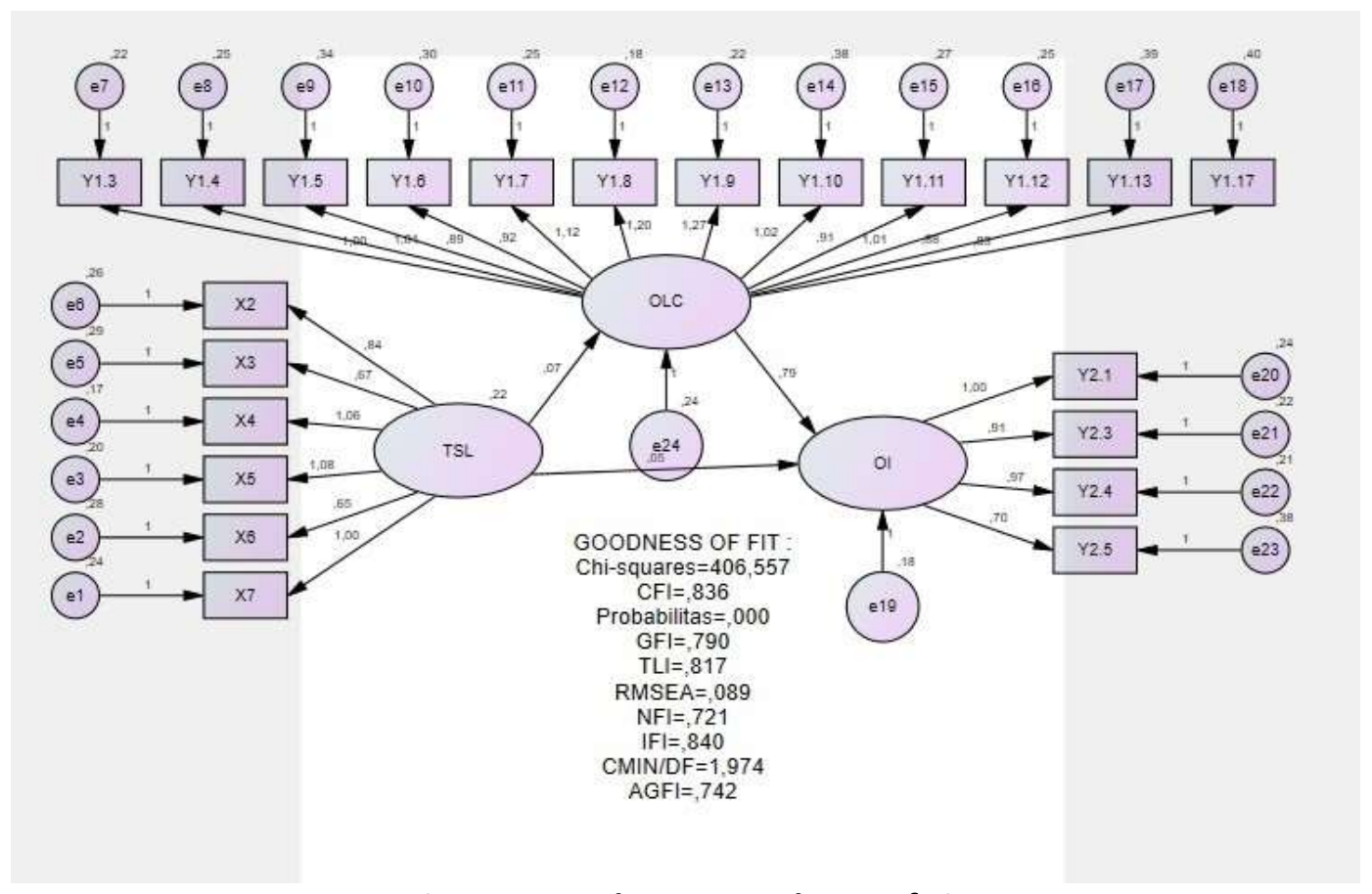

Figure 1 Result Test Goodness Of Fit

Source: Primary data processed 2019

Table 5 Test the Significance of Variables

\begin{tabular}{lllrrrrl}
\hline & & & Estimate & S.E. & C.R. & P & Explanation \\
\hline OLC & $<---$ & TSL &, 067 &, 108 &, 625 &, 532 & Rejected \\
OI & $<---$ & TSL &, 042 &, 109 &, 383 & $* * *$ & Accepted \\
OI & $<---$ & OLC &, 786 &, 135 & 5,845 & $* * *$ & Accepted \\
\hline
\end{tabular}

Source: Primary data processed 2019

Tabel 6 Indirect Effect Test Results

\begin{tabular}{lr} 
& Transactional Leadership \\
\hline Organizational Learning Capaility & $\ldots$ \\
Organization Innovativeness &, 044 \\
\hline
\end{tabular}

Source: Primary data processed 2019 
Tabel 7 Tabel Hipotesis

\begin{tabular}{|c|c|c|}
\hline No & Hipotesis & Explanation \\
\hline $\mathrm{H}_{1}$ & $\begin{array}{l}\text { Transactional leadership has a positive influence on } \\
\text { organizatinal learning capability (OLC) } \\
\text { Meaning: Transactional leadership has no influence in } \\
\text { improving organizational learning capability (OLC) }\end{array}$ & REJECTED \\
\hline $\mathrm{H}_{2}$ & $\begin{array}{l}\text { Transactional leadership has a positive influence on } \\
\text { organization innovativeness (OI) } \\
\text { Meaning: Transactional leadership can improve Organization } \\
\text { Innovativeness }\end{array}$ & ACCEPTED \\
\hline $\mathrm{H}_{3}$ & $\begin{array}{l}\text { Organizational learning capability (OLC) has a positive effect } \\
\text { on organization innovativeness (OI) } \\
\text { Meaning: Organizational learning capability can improve } \\
\text { organizational innovativeness (OI) }\end{array}$ & ACCEPTED \\
\hline $\mathrm{H}_{4}$ & $\begin{array}{l}\text { Organizational learning capability (OLC) mediates the } \\
\text { relationship between transactional leadership and } \\
\text { organizational innovativeness }(\mathrm{OI}) \\
\text { Meaning: Organizational learning capability cannot be a } \\
\text { mediator in the transactional leadership relationship to } \\
\text { organization innovativeness }\end{array}$ & REJECTED \\
\hline
\end{tabular}

Hypothesis 1 in the study shows that transactional leadership has no effect on OLC. This shows that in small business organizations it is possible to have a leadership style that encourages quick and flexible and market-oriented decisions. Some things that are thought to play a role in explaining OLC include leadership that is transformational and serving can be considered in the future.

Meanwhile, hypotheses 2 and 3 are supported empirically. Transactional leadership influences innovation in organizations. These results indicate that transactional leadership, which means maintaining a reciprocal relationship between employees and the organization fairly, has a fundamental role in building innovation. This result is supported by the AGA study (2016) and justice studies that play a role in the formation of positive behavior in organizations (Palupi \& Tjahjono, 2016; Palupi, Tjahjono, \& Fachrunnisa, 2019). Likewise, OLC has a positive effect on innovation supported empirically (Onag et al., 2014). Hypothesis 4 in this study is that the mediating role of OLC is not supported. Thus, the role of transactional leadership is quite important in explaining innovation in organizations.

\section{Conclusion}

Based on the results of statistical calculations that have been done, it can be seen that transactional leadership has no significant effect on organizational learning capability, which means that transactional leadership does not have an effect on improving organizational learning capability. This is certainly contrary to previous researchers, but there are several factors that could have produced these differences, namely: (1). 
Research Object, research in this object is a small and medium business which is a profit business while previous research combines the use of profit and non-profit businesses in research; (2). Culture, situations and conditions of research objects can produce different perspectives in answering questions about transactional leadership; (3) There is a stronger influence on organizational learning capability than other leadership styles, namely transformational leadership.

Based on the results of statistical calculations that have been done, it can be seen that transactional leadership has a positive and significant effect on the achievement of organization innovativeness. That is, the better the transactional leadership is applied, the better process of creating innovation in organizations to face increasingly fierce competition. Transactional leadership can guide an organization to innovate through work processes. A well-organized work process will make the organization have an opportunity to excel and be able to innovate through the work process of their organization. The results of this study are supported by previous research conducted by AGA (2016) which states that transactional leadership has a positive and significant effect on the achievement of organizational innovation.

Based on the results of statistical calculations that have been done, it can be seen that organizational learning capability has a positive and significant effect on the achievement of organizational innovativeness. That is, the better the organizational learning capablity is applied, it will improve the process of creating innovation in organizations to face increasingly fierce competition. Organizational learning capability can provide an analysis of work procedures or processes that cover every level in the organization to create innovation. Innovation creation can be adopted quickly to all parts of the organization only if the organization has a fast and responsive learning process. The results of this study are supported by previous research conducted by Onağ et al., (2014) which states that organizational learning capability has a positive and significant effect on the achievement of organizational innovation.

Based on the results of statistical calculations that have been done, it can be seen that organizational learning capability does not mediate transactional leadership towards achieving organizational innovativeness. This can be seen through the value of the indirect effect between transactional leadership on innovativeness organizations that have a smaller value than the value of the direct influence between transactional leadership and innovativeness organizations. Conceptually this is supported by the research of Rianse, et al (2015) which states that organizational learning capability does not mediate transactional leadership relationships to improve organizational innovativeness.

Suggestion

This research has heterogeneous respondents, which includes all types of small and medium businesses in the city of Kendari so that there is a possibility of bias respondents. Future studies are expected to examine more deeply about one type of business that is homogeneous. 
Based on the results of the study, the authors suggest that SMEs should make the learning process something that should be taken into consideration in making decisions to prepare their businesses to be superior in innovation.

\section{References}

Aga., A. D. (2016). Transactional leadership and project success: the moderating role of goal clarity. Procedia Computer Science, 100, 517 - 525. https://doi.org/10.1016/i.procs.2016.09.190

Aragon, C.J., García, M.J. \& Cordón, P. (2007), Leadership and organizational learning's role on innovation and performance: lessons from Spain. Industrial Marketing Management, 36(3), 349-359. https://doi.org/10.1016/i.indmarman.2005.09.006

Bass, B.M. (1985). Leadership and Performance Beyond Expectations. Free Press: Collier Macmillan.

Bass. B. M. \& Avolio, B.J. (1990). The implications of transactional and transformational leadership for individual team and organizational development. In B.M. Staw and I. Cummings (Eds.). Research in organizational change and development, 4, 231-272 Greenwich. C.T: JAI Press.

Bolden, R., Gosling, J., Marturano, A. \& Dennison, P. (2003). A review of leadership theory and competency frameworks. Report for Chase Consulting and the Management Standards Centre, Centre for Leadership Studies, University of Exeter.

Bowen, G.L. Rose, R. A., \& Ware, W. B. (2006). The reliability and validity of the school success profile learning organization measure. Evaluation and program planning. https://doi.org/10.1016/i.evalprogplan.2005.08.005

Chang, Y.C., Chang, H.T., Chi, H.R., Chen, M.H. \& Deng, L.L. (2012). How do established firms improve radical innovation performance? The organizational capabilities view. Tecbnovation, 32(7), 441-451. https://doi.org/10.1016/j.technovation.2012.03.001

Chiva, R. \& Alegre, J. (2008). Emotional intelligence and job satisfaction: the role of organizational learning capability. Personnel Review, 37(6), 680-701. https://doi.org/10.1108/00483480810906900

Ebrahimi P., Moosavi, S. Marzieh., \& Chirani, E. (2016), Relationship between Leadership Styles and Organizational Performance by Considering Innovation in Manufacturing Companies of Guilan Province, 3rd International Conference on New Challenges in Management and Organization: Organization and Leadership Dubai, Procedia - Social and Behavioral Sciences, 230, 351 - 358. https://doi.org/10.1016/j.sbspro.2016.09.044

Eisenbeiss, S.A., Van Knippenberg, D. \& Boerner, S. (2008). Transformational leadership and team innovation: integrating team climate principles. Journal of Applied Psychology, 93(6), 1438-1446. https://doi.org/10.1037/a0012716

Escrig, E. D., Mallén , F. B., Gomez, R. C., \& Alcami, R. L. (2016). How does altruistic leader behavior foster radical innovation? The mediating effect of organizational learning capability. Leadership \& Organization Development Journal, 37(8), 1056-1082. https://doi.org/10.1108/lodj-03-2015-0050

Fawcett, S.E., Andraski, J.C., Fawcett, A.M. \& Magnan, G.M. (2009). The art of supply change management. Supply Chain Management Review, 13(1), 18-25. https://doi.org/10.1108/13598540810850300

Goh, S. \& Richards G. (1997). Benchmarking the learning capability of organizations. European Management Journal, 15(5), 575-583. https://doi.org/10.1016/s0263$\underline{2373(97) 00036-4}$ 
Kara, D., Uysal, M., Sirgy, M.J. \& Lee, G. (2013). The effects of leadership style on employee wellbeing in hospitality. International Journal of Hospitality Management, 34, 9-18. https://doi.org/10.1016/i.ijhm.2013.02.001

Kuhnert, K.W. \& Lewis, P. (1987). Transactional and transformational leadership: a constructive/developmental analysis. Academy of Management Review, 12(4), 648-657. https://doi.org/10.5465/amr.1987.4306717

Majd, M. (2017). Leadership styles and organizational learning in UK for-profit and nonprofit sports organizations. International Journal of Organizational Analysis, 25(4), 596-612. https://doi.org/10.1108/ijoa-07-2016-1042

Morales, G., Jiménez, B. \& Gutiérrez, L. (2012). Transformational leadership influence on organizational performance through organizational learning and innovation. Journal of Business Research, 65(7), 1040-1050. https://doi.org/10.1016/i.jbusres.2011.03.005

Nonaka I, \& Takeuchi, H. (1995). The knowledge creating company: How Japanese companies create the dynamics of innovation. NewYork: Oxford University Press.

Nutt, P. (2002). Why Decisions Fail: Avoiding the Blunders and Traps that Lead to Debacles, BerrettKoehler Publishers, San Francisco, CA.

Onağ, O., Tepeci, M., Başalp, A. A. (2014). Learning Capability and its Impact on Firm Innovativeness. Procedia - Social and Behavioral Sciences, 150, 708-717. https://doi.org/10.1016/j.sbspro.2014.09.029

Palupi, M. \& Tjahjono, H.K. (2016). A model of religiousity and organizationaljustice: the commitment and dysfunctional behavior. Proceedings 27th IBIMA (International Business Information Management Association) Conference, Milan Italy.

Penn, A. (2015). Leadership Theory Simplified, University of Arkansas, United States Department of Agriculture, and County Governments Cooperating. Retrieved from https://www.uaex.edu/publications/PDF/FSPSD200.pdf

Rianse, U., Abdullah, G. W., \& Alwi, L. O. (2013). Analisis gaya belajar dan perilaku bisnis pengusaha kecil bidang agribisnis di Kota Kendari, AGRISEP, 12(2), 239-250. https://doi.org/10.31186/agrisep.12.2.239-250

Russell, E. (2011). Leadership theories and style: a traditional approach. Unpublished paper submitted for the General Douglas MacArthur Military Leadership Writing Competition.

Saadat, V. \& Saadat, Z. (2016). Organizational Learning as a Key Role of Organizational Success. Procedia - Social and Behavioral Sciences, 230, 219-225. https://doi.org/10.1016/i.sbspro.2016.09.028

Senge, P. (1990). The leader's new work: Building learning organization, Sloan Management Review, Fall, 7-23.

Setiawan, F. \& Tjahjono, H. K. (2016). Collective-Collegial: Leadership Model of Muhammadiyah Education. Proceedings of 28 th International Management Association Conference, 3595-3594 ISBN 978-0-9860419-8-3. Retrieved from http://eprints.uad.ac.id/8651/

Singh, K. (2008). Relationship between Learning Organization and Transformational Leadership: Banking Organizations in India. International Journal of Business and Management Science, 1(1): 97-111.

Tjahjono, H.K. \& Palupi, M. (2015). Kepemimpinan intrapersonal dan implikasi organisasional. Jurnal Bisnis: Teori dan Implementasi, 6(2), 207-215

Tjahjono, H.K. (2015). Metode Penelitian Bisnis. VSM MM UMY

Tjahjono, H.K.(2009). Hubungan budaya organisasional, keefektifan organisasional dan kepemimpinan: telaah perspektif untuk riset, $K O M P A K 10,132-148$. 
Tjahjono, H.K., Fachrunnisa, O. \& Palupi, M. (2019). Configuration of organizational justice and social capital: their impact on satisfaction and commitment. International Journal of Business Excellence, 17(3), 336-360. https://doi.org/10.1504/ijbex.2019.10019303

Vargas, M.I.R. (2015). Determinant Factors for Small Business to Achieve Innovation, High Performance and Competitiveness: Organizational Learning and Leadership Style,

Procedia - Social and Behavioral Sciences, 169, 43-52. https://doi.org/10.1016/i.sbspro.2015.01.284

Wang, C. L. \& Ahmed, P. K., (2004). The development and validation of the organisational innovativeness construct using confirmatory factor analysis. European Journal of Innovation Management, 7(4), 303-313. https://doi.org/10.1108/14601060410565056

Welirang, F. (2007). Revitalisasi Republik, Perspektif Pangan dan Kebudayaan. Grafindo. Jakarta. 